\title{
Factors Affecting Teacher Motivation in Nepal
}

\section{Dr. Peshal Khanal ${ }^{\star}$ Dr. Prem Phyak ${ }^{\dagger}$}

\begin{abstract}
The major aim of this paper is to report the finding of a study that aims at analyzing different factors influencing teacher motivation towards the teaching profession. To this goal, a mixed method approach was used and quantitative data were collected from 430 teachers, teaching at the Basic Level, from six districts using a set of questionnaires. Qualitative data were gathered from 48 teachers, six resources persons, six teacher trainers and three policy-makers. The major findings of the study show that multiple factors influence teacher motivation towards teaching profession, which are broadly categorized under four areas: individual, schoolrelated, sociocultural and political. Policy-related factors include salary and benefits, leave facility, promotion, training, pensions and freedom to trade union. Similarly, school-related factors for teacher motivation include school management, leadership, teaching load, professional development opportunities and feedback and reinforcement mechanism. Student-related factors contain class size, student composition, regularity, and discipline. Socio-cultural factors for teacher motivation include social recognition of teachers, political interference and teacher-parent cooperation. Finally, the issue of teacher performance and motivation should be tied up with the policies of teacher professional development.
\end{abstract}

Keywords: teacher, motivation, professional development, school, Nepal

* Dr. Peshal Khanal is Associate Professor at Central Department of Education, Tribuvan University. Email: peshal.khanal@tucded.edu.np

$\dagger$ Dr. Prem Phyak is Associate Professor at Central Department of Education, Tribhuvan University. Email: prem.phyak@tucded.edu.np 


\section{Introduction}

Teacher motivation is a key to the quality learning in schools. While teacher motivation remains always at the heart of educational policies and reform agenda both in Nepal and beyond, this concept has been defined in multiple ways by different scholars. While some define it as attraction towards teaching profession (e.g. Sinclair, 2008), others take it as teachers' commitment towards putting efforts in transforming teaching practices. Sinclair's (2008) definition provides an overarching framework to understand what teacher motivation is and how it is linked with teacher professional development. For Sinclair, teacher motivation is about "what attracts individuals to teaching, how long they remain in [...] the teaching profession, and the extent to which they engage with [...] the teaching profession" (2008, p. 37). This definition indicates that teacher motivation refers to teachers' attraction towards teaching profession and their longterm concentration and commitment in the profession.

Dörnyei and Ushioda (2011) specify two major dimensions of teacher motivation. For them, teacher motivation includes 'motivation to teach' and 'motivation to remain in the job'. Based on this idea, Han and Yin (2016) specify four components of teacher motivation: intrinsic motivation; external factors (sociopolitical and cultural factors) influencing motivation; long-term commitment in teaching; and factors that demotivate teachers. Building on these literatures, this study explores Nepalese teachers' motivation in terms of job satisfaction, continuity or discontinuity of job, self-initiatives to improve teaching, and external factors that affect teaching. More importantly, this study aimed at analyzing the link between teacher motivation and teacher professional development.

\section{Method}

The study has adopted a mixed method approach to educational research, particularly teacher motivation and teacher professional development, to collect necessary information from teachers, Teacher Professional Development (TPD) trainers, resource persons (RPs) and policy-makers.

A set of survey questionnaire was developed to collect information related to the status of teacher motivation. The questionnaire covered both 'work context factors' (e.g. availability of facilities, institutional support, class 
size, infrastructures, incentives/salaries, sociopolitical dynamics, job security etc.) and 'work content factors' (e.g. opportunities for professional development, recognition/identity, workload, knowledge about content) affecting teacher motivation and teacher professional development. The questionnaire also included questions related to policy and sociopolitical factors that impact on teacher motivation for effective teaching and professional development. In addition, the questions related to opportunities and barriers for effective teaching were also included in the questionnaire. The survey was conducted among 430 teachers from six districts - Kalikot, Kavre, Achcham, Okhaldhunga, Kapilbastu and Sarlahi. The sampling criteria include the following: normal deviation set at $95 \%$ confidence level $(\mathrm{CI} 95 \%=1.96), \mathrm{sd}=$ standard deviation $(50 \%=0.5), \mathrm{e}=$ margin of error (confidence interval) $(5 \%=0.05)$.

Along with survey, six focus group discussions (FGDs), one each from six sample districts were conducted with the teachers. The number of teachers participated in FGDs was 48 in total. These teachers were those who did not participate in the survey. These discussions have been focused on issues related to teacher motivation, opportunities and barriers for effective teaching, the existing policies and practices of professional development and alternative ideas for improving TPD. These discussions were recorded by using digital voice recorders which were later transcribed for data analysis purposes. In addition, the perspectives of teachers were documented in the form of field notes. One class from one school in each district was also observed in order to understand actual classroom practices of teachers and facilitate critical discussions in focus groups. The researcher also conducted in-depth interviews with six Resource Persons and six TPD trainers-one from each district-to understand the current situations of TPD, teachers' expectations and motivation and alternative perspectives of TPD. In addition, the team members had in-depth interviews with representatives of Department of Education (DoE) and National Centre for Educational Development (NCED) in Kathmandu in July 2017.

The researcher used CSPro software in Android to manage quantitative data collected from the sample teachers. Qualitative data were stored in Live scribe and audio-recorder, which were transcribed and coded to generate themes. These themes were organized under the broader themes of the study.

\section{Concept and theories of teacher motivation: A literature review}

Scholars have discussed two dominant theories of teacher motivation. These theories include self-determination theory and achievement goal 
theory (Richardson \& Watt, 2016). In this section, these theories have been discussed briefly.

\section{Self-determination theory}

Self-determination theory of teacher motivation makes a distinction between intrinsic and extrinsic motivation and "the quality of experience and performance can be very different when one is behaving for intrinsic versus extrinsic reasons" (Ryan \& Deci, 2000, p. 55). While intrinsic motivation directs teachers towards better learning opportunities, extrinsic motivation is concerned with gaining material advantage. Intrinsic motivation is natural and arises out of human psychological needs "for competence, autonomy and relatedness" Ryan \& Deci, 2000, p. 57). Yet, external conditions may promote or hinder intrinsic motivation. Studies have shown that if teachers feel competent and autonomous, they become more intrinsically motivated. In contrast, intrinsic motivation decreases if people feel that they are being controlled and their sense of self is not acknowledged.

Unlike intrinsic motivation, extrinsic motivation is more instrumental than autonomous in its nature. Organic Integration Theory (OIT), a subtheory of self-determination theory, introduces different forms of extrinsic motivation: external regulation (i.e. activities conducted to satisfy others); introjected motivation (i.e. activities conducted to maintain self-esteem though the activities are proposed by others); identification (i.e. activities conducted because of their personal value); and integrated regulation (i.e. full acceptance of external regulation) (Ryan \& Deci, 2000). These forms of motivation are directly related to teachers' motivation for professional development. Whether or not teachers are highly motivated towards their professional development can be assessed by looking at how teachers are regulated-whether or not their personal values are accepted-and how teachers actually feel when they are being regulated.

One of the major issues is that teachers engage in external regulated activities if they really value the person who initiates the activities and have a sense that the initiators have competence to carry out the activity. Roth, Assor, KanatMaymon, and Kaplan (2007) found that teachers' high level of autonomous motivation was significantly correlated with a greater sense of achievement whereas the controlled motivation was correlated with exhaustion. Similarly, high degree of autonomous motivation of teachers was correlated with greater students' autonomy in learning thereby contributing to autonomous motivation in learning which in turn contributes to competence-based learning. 


\section{Achievement goal theory}

The achievement goal theory of teacher motivation assumes that motivation depends on the goals that teachers set for their teaching (Butler, 2007). Butler (2007) proposes four types of goals: (a) learn, develop, and acquire professional understandings and skills (mastery orientation); (b) demonstrate superior teaching ability (ability approach); (c) avoid the demonstration of inferior teaching ability (ability avoidance); and (d) get through the day with a little effort (work avoidance) (p. 242). These factors are key to understanding teacher motivation. Studies have shown that teachers whose goals are oriented to mastery seek help from other teachers while the teachers, who are oriented towards avoiding their inferior teaching ability, did not like to seek help. Similarly, teachers who tend to avoid work are also likely to seek any help if they think that it would make their work easier.

Similar to Butler's (2007) goal category, Shim, Cho, and Cassady (2013) propose a three-structure framework of achievement goals for teachers: mastery goals, performance goals, and performance avoidance goals. The type of achievement goals endorsed by schools can have impact on teachers' achievement goals, which in turn, influence the goal they set for their own classroom. To explain this further, "when schools overly stress the importance of high test scores, academic competition, and use the highest achieving students as models for all students, teachers [...] may be more likely to use performance-oriented instructional practices in the classroom" (Butler, 2007, p.551). Butler (2007) further argues that "teachers who approach their teaching with the desire to improve their teaching competence tended to promote mastery goals for their students and value all students' progress and learning" (p.99-100). In contrast, "teachers who strive to demonstrate their superior teaching ability to their principal or other colleagues (performance-approach goals) were more likely to encourage competition among students" (pp. 99-100). This implies that mastery goals are more beneficial for both teachers and students than performance goals.

\section{Factors affecting teacher motivation: Findings and discussion}

This study has identified factors that affect teachers' motivation in four areas: policy-related, school-related, student-related, and society and culture-related. 


\section{Policy related factors}

NCED has developed and implemented a number of policies to strengthen teacher motivation. Such policies include salary, leave facilities, promotion and incentive, in-service training, retirement pensions, teacher recruitment, transfer and freedom to form unions. Overall, in terms of impact on teacher motivation these policies, except for in-service teacher training, have a below average impact on teacher motivation (see Table 1). Although majority of teachers $(84.2 \%)$ are familiar with these policies, they have rated the impact of all the existing policies as 'low-motivating'. In-service teacher training has an average impact (1.03) on teacher motivation. For the teachers in this study, 'freedom to form teachers' unions' (impact=0.55) and 'in-service promotion' (impact=0.58) policies are quite 'demotivating' for their professional growth.

As emerged from focus group discussions in all six districts, teachers have opined that freedom to form teachers' unions have promoted direct political intervention in school-related activities. For example, one teacher from Kapilvastu has said, "these days, teachers are involved in party politics. They are not worried about teaching and improved student learning outcomes. As teachers have strong political protection, nobody can punish the teachers who are not committed to their profession." Another teacher from Kalikot has said, "due to politicization of education, the issue of professionalism has not been given a high priority. Teachers are rewarded on the basis of their political affiliation rather than on the basis of their professional quality. It is bizarre. Our policy makers should rethink about this practice."

\section{Table 1: Policy provisions for teacher motivation}

\begin{tabular}{|c|c|c|c|c|c|c|}
\hline \multirow[b]{2}{*}{ Policy provisions } & \multirow{2}{*}{\begin{tabular}{|c} 
Fa- \\
mil- \\
iarity \\
(\% of \\
Yes)
\end{tabular}} & \multicolumn{5}{|c|}{ Impact on Motivation } \\
\hline & & $\begin{array}{l}\text { Doesn't } \\
\text { make } \\
\text { any dif- } \\
\text { ference }\end{array}$ & $\begin{array}{l}\text { Mo- } \\
\text { tivat- } \\
\text { ing }\end{array}$ & $\begin{array}{c}\text { High- } \\
\text { ly mo- } \\
\text { tivat- } \\
\text { ing }\end{array}$ & $\begin{array}{c}\text { Total } \\
\%\end{array}$ & $\begin{array}{c}\text { Average } \\
\text { motiva- } \\
\text { tion lev- } \\
\text { el }(=1)\end{array}$ \\
\hline Salary and benefits & 91.4 & 31.0 & 59.5 & 9.4 & 100.0 & 0.78 \\
\hline Leave facility & 95.6 & 23.4 & 61.6 & 15.1 & 100.0 & 0.92 \\
\hline In-service promotion & 77.9 & 54.3 & 33.1 & 12.5 & 100.0 & 0.58 \\
\hline $\begin{array}{l}\text { In-service incentive } \\
\text { (grade) }\end{array}$ & 76.5 & 40.7 & 38.6 & 20.7 & 100.0 & 0.80 \\
\hline
\end{tabular}




\begin{tabular}{|l|l|l|l|l|l|l|}
\hline $\begin{array}{l}\text { In-service teacher } \\
\text { training }\end{array}$ & 81.4 & 19.7 & 57.4 & 22.9 & 100.0 & 1.03 \\
\hline Retirement pensions & 84.7 & 38.7 & 29.1 & 32.1 & 100.0 & 0.93 \\
\hline $\begin{array}{l}\text { Teacher recruitment } \\
\text { practice }\end{array}$ & 89.8 & 29.8 & 55.7 & 14.5 & 100.0 & 0.85 \\
\hline Transfer and posting & 80.0 & 50.3 & 35.2 & 14.5 & 100.0 & 0.64 \\
\hline Freedom to trade union & 80.7 & 55.3 & 34.3 & 10.4 & 100.0 & 0.55 \\
\hline Composite index & 84.2 & 37.6 & 45.6 & 16.8 & 100.0 & 0.79 \\
\hline
\end{tabular}

Source: Field Survey, 2017.

Teacher transfer and posting (impact=0.64) and salary/benefits (impact $=0.78$ ) are two other policy provisions that have least impact on teacher motivation. Similarly, the existing in-service incentive (impact $=0.80$ ) and teacher recruitment practice (impact $=0.85$ ) have a significant impact on teacher motivation. This data clearly indicates that the existing policies of forming teachers' union, teacher promotion and incentivization, and teacher recruitment practices should be revised and reformulated.

\section{School related factors}

The school environment plays a critical role to shape teacher motivation. In this study, the teachers' responses clearly show that different school related factors have both positive and negative impacts on teacher motivation. As seen in Table 2 most school related factors have an average impact on teacher motivation. The data show that support (impact=2.07) and cooperation (impact=2.18) between teachers are more motivating than other factors for teachers. The data also show that school management system (impact=1.87), head teachers' leadership (impact=1.97), teaching load (impact=1.90) and head teachers' feedback (impact $=1.90$ ) have impact on teacher motivation slightly higher than the average. 
Table 2: Impact of school related factors on teacher motivation

\begin{tabular}{|l|l|l|l|l|l|l|}
\hline \multicolumn{1}{|c|}{ School related factors } & $\begin{array}{c}\text { Demo- } \\
\text { tivat- } \\
\text { ing }\end{array}$ & $\begin{array}{c}\text { Low } \\
\text { moti- } \\
\text { vat- } \\
\text { ing }\end{array}$ & $\begin{array}{c}\text { Mo- } \\
\text { ti- } \\
\text { vat- } \\
\text { ing }\end{array}$ & $\begin{array}{c}\text { High- } \\
\text { ly } \\
\text { moti- } \\
\text { vating }\end{array}$ & $\begin{array}{c}\text { Aver- } \\
\text { Total } \\
\text { age mo- }\end{array}$ & $\begin{array}{c}\text { tivation } \\
\text { (=1.5) }\end{array}$ \\
\hline $\begin{array}{l}\text { A. School management } \\
\text { system }\end{array}$ & 9.1 & 14.7 & 66.7 & 9.5 & 100.0 & 1.8 \\
\hline B. Head teacher's leadership & 5.3 & 11.4 & 64.4 & 18.8 & 100.0 & 2.0 \\
\hline C. Teaching load & 1.2 & 13.3 & 80.5 & 5.1 & 100.0 & 1.9 \\
\hline $\begin{array}{l}\text { D. Teacher-teacher } \\
\text { cooperation }\end{array}$ & 2.1 & 4.0 & 67.9 & 26.0 & 100.0 & 2.2 \\
\hline $\begin{array}{l}\text { E. Professional development } \\
\text { opportunities }\end{array}$ & 13.5 & 20.9 & 52.8 & 12.8 & 100.0 & 1.6 \\
\hline $\begin{array}{l}\text { F. Incentives and appreciation } \\
\text { system }\end{array}$ & 40.2 & 24.7 & 23.5 & 11.6 & 100.0 & 1.1 \\
\hline $\begin{array}{l}\text { G. Availability of teaching } \\
\text { resources }\end{array}$ & 9.8 & 21.6 & 55.8 & 12.8 & 100.0 & 1.7 \\
\hline $\begin{array}{l}\text { H. Participation in decision- } \\
\text { making process }\end{array}$ & 9.1 & 16.3 & 62.6 & 12.1 & 100.0 & 1.8 \\
\hline $\begin{array}{l}\text { I. Regular } \\
\text { feedback/reinforcement from } \\
\text { head teachers }\end{array}$ & 7.0 & 13.7 & 61.6 & 17.7 & 100.0 & 1.9 \\
\hline J. Support from colleagues & 2.8 & 7.0 & 70.9 & 19.3 & 100.0 & 2.1 \\
\hline $\begin{array}{l}\text { K. Lack of clear } \\
\text { guidelines/support for } \\
\text { teaching }\end{array}$ & 16.3 & 27.0 & 48.6 & 8.1 & 100.0 & 1.5 \\
\hline Composite index & 10.6 & 15.9 & 59.6 & 14.0 & 100.0 & \\
\hline
\end{tabular}

Source: Field Survey, 2017.

Although professional development opportunities (impact=1.65), availability of teaching resources (impact=1.72) and participation in decision making process (impact $=1.78$ ) have above the average score, the existing incentive and appreciate system is quite demotivating for teachers (impact=1.07). Likewise, teachers find lack of clear guidelines and the system of regular support as two demotivating factors for them (impact=1.49). This data indicate that the existing teacher incentive system and support mechanism are not contributing to teacher motivation. This 
situation clearly indicates that the teachers should be provided with clear guidelines and regular support to keep them motivated for teaching.

Teachers and Resource Persons (RPs) have made some critical comments regarding the impact of school related factors on teacher motivation. Commenting on the incentive and appreciation system, the teachers from all districts have contended that they are not punished and rewarded on the basis of professional rigor, rather by their loyalty to political parties. One teacher from Siraha, for example, has stated:

The existing reward and punishment practices are not logical. Teachers who worked hard and teach khuru khuru (regularly) by implementing the knowledge they have learned from TPD trainings are not rewarded. We have seen that the teachers who do not take classes regularly but are closed to District Education Officer and political leaders are rewarded as the best teachers. So, hard-working teachers are not motivated to teach.

One RP from Okhaldhunga, from example, reveals that in some school head teachers and teachers do not have a good relation as they belong to different political parties. He further says "I have seen that head teachers even cannot suggest teachers to improve their teaching due to their political differences. It is not quite easy to work in this kind of environment."

Another teacher from Kalikot further contended that "if the value of teacher's professionalism is not recognized then teachers become demotivated in teaching. The teachers who would like to change their teaching practices and committed to improve quality of students' learning do not have recognition." An RP from Dailekh has a similar view:

I have taught for 28 years. I started teaching at a primary school. I have never been promoted and rewarded by looking at my professional experience and competence. It may sound like I am opposing the existing system, but it is reality. Teachers are questioning why they need to teach in school if they do not know who is promoted and rewarded after all. This is a main grievance most teachers have.

The teachers in this study have also pointed out that there is lack of clear guidelines and support in order to implement knowledge and skills they have learned from teacher training. One teacher from Achcham, for example, has said, "We do not have any person to discuss and share our problems we face while implementing what we learn from teacher training." The teachers have also pointed out the lack of infrastructure and resources as 
factors affecting their motivation for effective teaching. In Okhaldhunga, teachers have stated that their classrooms are 'not appropriate to conduct group and pair work activities.'

\section{Box 1: Teachers' view on resource and facilities}

Our school does not have an appropriate infrastructure, adequate educational teaching materials, and teachers darbandi. Teachers are

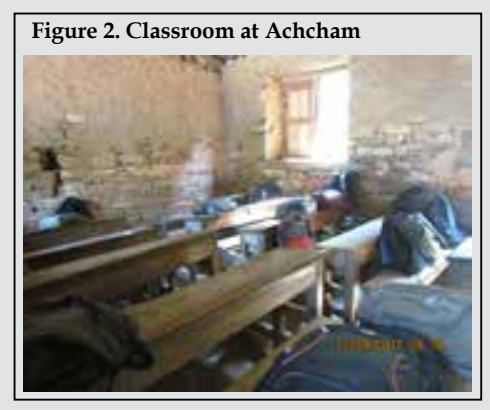
not posted as per the demand of school. One teacher must take multiple classes at the same period (ghanti). There are no adequate rooms, desks and benches, chalks or board markers and dusters. How can a teacher teach effectively in this situation by using the knowledge of TPD training? Despite this situation, we are enjoying teaching job from early 10 am to 4 pm every day. Parents do not know about school environment, but what they know is that they children must pass examinations with an ' $\mathrm{A}$ ' grade. We feel uncomfortable when parents blame us that we are not teaching well. So far as student performance is concerned, not only teachers, but also parents, School Management Committee (SMC), political parties and even students are responsible.

(Focus Group Discussants of Shree Mangala Rastriya Madhyamic Bidhyalaya, Mangalsen Municipality-9, Achham).

\section{Student related factors}

This study has also explored the role of student-related factors in shaping teacher motivation. These factors include the number of students, student diversity in terms of ability and language/culture, and student regularity, discipline and achievement. As seen in Table 3, teachers consider most of these factors motivating. Yet, they pointed out that 'children's failure despite their hard work' (impact=1.24) is the most frustrating factor that negatively impacts on their motivation to teach. 
Table 3: Impact of student related factors

\begin{tabular}{|l|l|l|l|l|l|l|}
\hline \multicolumn{1}{|c|}{ Factors } & \multicolumn{1}{|c|}{$\begin{array}{c}\text { Low } \\
\text { Demo- } \\
\text { tivating }\end{array}$} & $\begin{array}{c}\text { Hotiva- } \\
\text { ting }\end{array}$ & $\begin{array}{c}\text { Moti- } \\
\text { vating }\end{array}$ & $\begin{array}{c}\text { Highly } \\
\text { moti- } \\
\text { vating }\end{array}$ & $\begin{array}{c}\text { Ave- } \\
\text { Total } \\
\text { rage }\end{array}$ \\
\hline $\begin{array}{l}\text { A. Large student } \\
\text { number }\end{array}$ & 7.9 & 24.2 & 56.5 & 11.4 & 100.0 & 1.71 \\
\hline $\begin{array}{l}\text { B. Student } \\
\text { diversity in terms } \\
\text { of ability }\end{array}$ & 5.8 & 27.0 & 58.6 & 8.6 & 100.0 & 1.70 \\
\hline $\begin{array}{l}\text { C. Students' } \\
\text { diversity in } \\
\text { language and } \\
\text { culture }\end{array}$ & 5.6 & 23.0 & 60.7 & 10.7 & 100.0 & 1.77 \\
\hline $\begin{array}{l}\text { D. Students' } \\
\text { regularity }\end{array}$ & 7.2 & 24.4 & 51.6 & 16.7 & 100.0 & 1.78 \\
\hline $\begin{array}{l}\text { F. Students' } \\
\text { discipline }\end{array}$ & 2.8 & 15.6 & 63.7 & 17.9 & 100.0 & 1.97 \\
\hline $\begin{array}{l}\text { G. Children failure } \\
\text { despite trying my } \\
\text { best }\end{array}$ & 17.0 & 44.4 & 36.5 & 2.1 & 100.0 & 1.24 \\
\hline Composite index & 8.1 & 26.8 & 54.2 & 10.8 & 100.0 & - \\
\hline
\end{tabular}

Source: Source: Field Survey, 2017.

The teachers in all districts have pointed out that children are not learning although they work hard to support them. One striking issue that has emerged from focus group discussion is that the existing practice of continuous assessment system (CAS) has not been quite helpful for quality student learning. Most teachers have considered this system as a way to pass students without enhancing quality learning. 


\section{Box 2: Teachers' view on CAS}

Continue Assessment System (CAS) has increased regularity of students in school. The students who attend 75 percent and more classes will be promoted to the next Grade, without taking an examination. CAS is implemented to increase children's attendance in school. But teachers have misinterpreted the system that they do not have to teach; they think that children will be promoted without taking any examinations. In CAS, students receive 75 percent of total marks for the attendance at 1-5 Grades and 50 percent at 6-8 Grades. CAS is understood in another way that students do not have to study but simply attend school in the first hour (before the interval), and leave the school, for various reasons, by the end of the day. For example, there are 30 students at Grade 8, and all of them are present during the roll call [which is usually done in the first hour of the day]. But at the end of the day hardly 10-12 students remain in the school. This has discouraged the teachers to work hard to teach students.

(Focus Group Discussants, Saraswati High School, Dailekh)

\section{Sociocultural and political factors}

Studies have shown that sociocultural and political factors can significantly influence teacher motivation (Guskey, 2000). Such factors include social recognition of teachers, teacher-community relations, teacher-parent interactions, political dynamics of community and parents' socioeconomic background. In order to understand the role of sociopolitical factors in teacher motivation, a rating scale question has been asked to the teachers in that they could give a numerical value to specific sociocultural and political factors. As see in Table 4, in average, the teachers have rated almost all sociocultural factors 'motivating'. However, two major factors political interference in school and parents' socioeconomic and educational backgrounds are 'demotivating' for them. 


\section{Table 4: Impact of sociocultural factors}

\begin{tabular}{|l|l|l|l|l|l|l|}
\hline \multicolumn{1}{|c|}{ Factors } & $\begin{array}{c}\text { De- } \\
\text { mo- } \\
\text { tivat- } \\
\text { ing }\end{array}$ & $\begin{array}{c}\text { Low } \\
\text { mo- } \\
\text { tivat- } \\
\text { ing }\end{array}$ & $\begin{array}{c}\text { Mo- } \\
\text { tiva- } \\
\text { ting }\end{array}$ & $\begin{array}{c}\text { High- } \\
\text { ly mo- } \\
\text { tiva- } \\
\text { ting }\end{array}$ & $\begin{array}{c}\text { To- } \\
\text { tal } \\
\text { \%o }\end{array}$ & $\begin{array}{c}\text { Ave- } \\
\text { rage } \\
\mathbf{( = 1 . 5 0 )}\end{array}$ \\
\hline $\begin{array}{l}\text { A. Social recognition of } \\
\text { teachers }\end{array}$ & 3.0 & 10.9 & 65.1 & 20.9 & 100.0 & 2.04 \\
\hline $\begin{array}{l}\text { B. Teacher-community } \\
\text { relation }\end{array}$ & 3.0 & 12.1 & 66.3 & 18.6 & 100.0 & 2.00 \\
\hline $\begin{array}{l}\text { C. Teacher-parent } \\
\text { cooperation }\end{array}$ & 10.2 & 21.9 & 55.1 & 12.8 & 100.0 & 1.70 \\
\hline $\begin{array}{l}\text { D. Political interference in } \\
\text { school activities }\end{array}$ & 31.9 & 33.5 & 28.8 & 5.8 & 100.0 & 1.09 \\
\hline $\begin{array}{l}\text { E. Parents' socioeconomic } \\
\text { background }\end{array}$ & 16.0 & 36.5 & 39.5 & 7.9 & 100.0 & 1.39 \\
\hline $\begin{array}{l}\text { F. Cultural differences bet. } \\
\text { comm. \& teachers }\end{array}$ & 4.4 & 24.9 & 62.6 & 8.1 & 100.0 & 1.74 \\
\hline G. Family support & 0.2 & 3.3 & 35.6 & 60.9 & 100.0 & 2.57 \\
\hline Composite index & 9.8 & 20.4 & 50.4 & 19.3 & 100.0 & - \\
\hline
\end{tabular}

Source: Field Survey, 2017.

The data show that political interference in school activities is the most 'demotivating' factor for the teachers (average=1.09). Similarly, parents' socioeconomic and educational background is found to be less motivating for teachers (1.39). As mentioned above, teachers in all six districts think that direct political interference in school is not encouraging for their professional growth and quality student learning. They have pointed out that the implementation of new practices such as children-friendly and studentcentered approach have been difficult due to parents' lack of awareness on the importance of these practices. A teacher from Okhaldhunga said, "We try to teach students by using a play technique and group work in classroom. But parents think that we are not actually teaching. For them, teaching means reading textbooks aloud, keeping students silent and disciplined, and providing them with a lot of homework. We have heard complaints from parents that they do not like their children to be involved in discussions and games, but they think that children should be taught." 


\section{Conclusion and implications}

This paper has analyzed various factors affecting teacher motivation. One of the striking findings is that all the existing policies are not quite motivating for teachers. As teachers have pointed out, political interference through the formation of teachers' union in school and unfair incentive and reward system are quite demotivating. Parents' lack of awareness on what counts as effective teaching-learning processes is another demotivating factor for teachers to teach with new ideas. Based on the findings the main conclusion of this paper are as follows:

o One of the major factors influencing teacher motivation towards the teaching profession is job satisfaction. In this study, although majority of teachers have chosen teaching job because they would love to work with children. They, particularly temporary teachers, are less satisfied with their job. On the one hand, they are not provided with equal opportunities and facilities for professional development, and on the other, their voices are given less importance in decision making processes.

o This study shows that teachers with a permanent tenure, receiving a full salary and any TPD training, are more satisfied with their job and motivated towards teaching profession. Yet, about sixteen percent of teachers want to discontinue their job and majority of them show a withdrawal syndrome in terms of their motivation for teaching.

o Although majority of teachers are familiar with the existing policies for teacher motivation, they have rated the impact of most of these policies as low-motivating. Among them, freedom to form teachers' union (impact $=0.55$ ) and in-service promotion policies (impact $=0.58$ ) are considered the most demotivating for teachers' professional growth.

o The existing incentive and appraisal system and the practice of support and feedback for teachers are among the most demotivating factors for teachers.

o Children's repeated failure despite teachers' continual efforts is another important factor affecting teacher motivation.

o The study shows that political interference in school is one of the most demotivating factors for teachers. In addition, parents' 
socioeconomic and educational background is less motivating for teachers. Teachers have pointed out that the implementation of new practices such as children-friendly and student-centered approach have been difficult due to parents' lack of awareness on the importance of these practices.

Based on the above findings and conclusion, this paper draws three major implications for policies and practice:

o Focus on achievement goal approach: The existing framework of NCED mentions the importance of teacher motivation as part of TPD, but it lacks a clear outline and specific activities that focus on teacher motivation. Although the scope of teacher motivation itself is a broad and relevant approach to strengthen teacher motivation could an achievement goal approach in that teachers are first engaged in setting up their own goals and develop a plan for achieving those goals. Rather than deciding on what teachers needs in a top-down manner, this approach will engage teachers not only to understand what their goals are but also identify the competencies and skills they need to achieve those goals.

o Portfolio-based assessment and regular feedback mechanism: A portfolio-based assessment could be an alternative approach in the existing TPD program. In this approach, teachers are assessed on the basis of what they have performed. In order to support teachers to strengthen their portfolio and provide feedback, there should be a feedback and support system at the school level. For this purpose, highly experienced experts could be hired at the local level. Such experts will collaborate with teachers towards strengthening their capacity and performance.

o Funding for innovations in teaching: Each school should be provided with additional funding for innovations in teaching. For this purpose, teachers will propose a new approach of teaching to improve students' learning, and they will be provided with additional funding to experiment new ideas.

\section{Acknowledgement}

The author acknowledges the Save the Children Nepal for funding to undertake this study. 


\section{References}

Butler, R. (2007). Teachers' achievement goal orientations and associations with teachers' help seeking: Examination of a novel approach to teacher motivation. Journal of Educational Psychology, 99(2), 241-252. https:/ / doi.org/10.1037/0022-0663.99.2.241

Dornyei, Z., \& Ushioda, E. (2011). Teaching and researching motivation (2 ${ }^{\text {nd }}$ Ed.). Harlow: Pearson.

Guskey, T. R. (2000). Evaluating professional development. Thousand Oaks, CA: Corwin Press.

Han, J. \& Yin, H. (2016). Teacher motivation: Definition, research development and implications for teachers, Cogent Education, 3(1), 1- 18. https://doi.org/10.1080/ 2331186X.2016.1217819

Richardson, P. W. \& Watt, H. M. G. (2016). Factors influencing teaching choice: Why do future teachers choose the career? In International Handbook of Teacher Education (Vol. 2, pp. 275-304). Singapore: Springer.

Roth, G., Assor, A., Kanat-Maymon, Y. \& Kaplan, P. (2006). Assessing the experience of autonomy in new cultures and contexts. Motivation and Emotion, 30, 365-376.

Ryan, R. M. \& Deci, E. L. (2000). Self-determination theory and the facilitation of intrinsic motivation, social development, and well-being. American Psychologist, 55, 68-78.

Shim, S. S. Cho, Y., \& Cassady, J. (2013). Goal structures: The role of teachers' achievement goals and theories of intelligence. The Journal of Experimental Education, 81, 84-104. http://dx.doi.org/10.1080/00220973.2011.635168

Sinclair, C. (2008). Initial and changing student teacher motivation and commitment to teaching. Asia Pacific Journal of Teacher Education, 36(2), 79-104. https://doi. org/10.1080/13598660801971658 